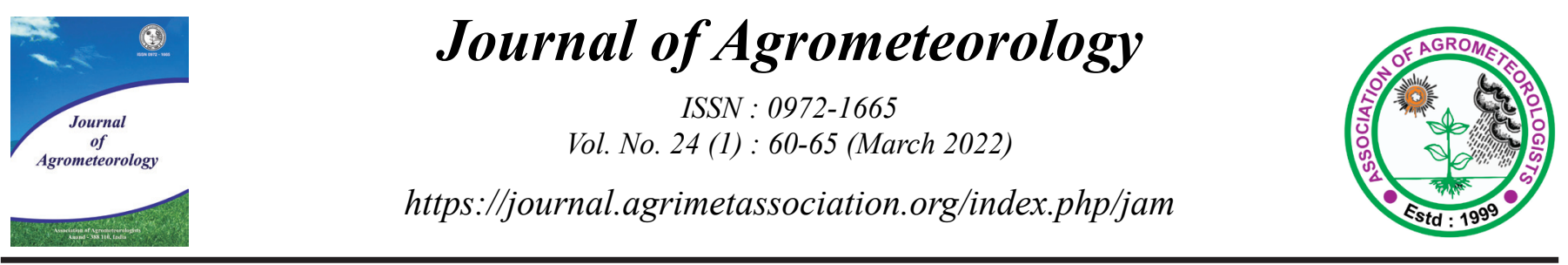

Research Paper

\title{
Effect of weather parameters, host resistance and sowing environment on disease severity and temporal dynamics of Fusarium wilt in chickpea (Cicer arietinum L.)
}

\author{
ANNIE KHANNA ${ }^{*}$, KUSHAL RAJ ${ }^{1}$ and PANKAJ KUMAR ${ }^{2}$ \\ ${ }^{1}$ Dept of Plant Pathology, CCS Haryana Agricultural University, Hisar, India \\ ${ }^{2}$ Dept of Floriculture and Landscaping, Punjab Agricultural University, Ludhiana, India \\ *Corresponding author email : anniekhanna30@gmail.com
}

\begin{abstract}
Fusarium wilt incited by Fusarium oxysporum f. sp. ciceris is an economically damaging disease of chickpea (Cicer arietinum L.). Field experiments on epidemiological studies revealed that sowing during second fortnight of November curtailed the disease severity index (22.50 and $20.83 \%$ during 2018 - 19 and 2019-20, respectively) whereas, sowing during first fortnight of October enhanced the disease severity index (34.86 and $30.41 \%)$. The area under disease progress curve was significantly higher in susceptible variety JG 62 and was the least in resistant variety HC 1 . The correlation analysis exhibited positive correlation of disease severity index with maximum and minimum temperature while negative correlation with relative humidity (morning and evening both), irrespective of sowing environments. The principal component analysis depicted resistance index, sowing time and weather parameters as positional factors in determining Fusarium wilt progression. In susceptible variety, Gompertz model was the best fitted model for simulating the Fusarium wilt epidemic over time.
\end{abstract}

Key words: Chickpea, disease progression, Fusarium wilt, weather parameters

Chickpea (Cicer arietinum L.) is the most important legume crop in India which is cultivated over an area of 9.44 Mha with a production and productivity of $10.13 \mathrm{MT}$ and $1073 \mathrm{~kg} / \mathrm{ha}$, respectively (Anon., 2019). Besides having high lysine rich protein, it also plays a significant role in atmospheric nitrogen fixation. Fusarium wilt caused by Fusarium oxysporum f. sp. ciceris is one of the most devastating diseases inflicting yield losses up to $94 \%$ (Jimenez-Diaz et al., 2015). The disease is widespread in most chickpea growing areas in Africa, southern Europe, America and Asia including India (Jimenez-Diaz et al.,2015).

Sowing of chickpea varieties at different times subject the vegetative and reproductive stages to various temperatures, solar radiation and day length (Tyagi, 2014). The total outcome of disease depends upon the interaction of three factors viz., host's resistance level, pathogen's virulence level and predisposing factors exerted by prevailing environmental conditions (Van der Plank, 1963). Temperature ranging from $20-30^{\circ} \mathrm{C}$ favors the disease development and helps in predisposing chickpea plants to Fusarium wilt infection (Landa et al., 2001; Sudharani et al., 2019). Jalali and Chand (1992) highlighted the use of resistant variety as the most economical and practical means of managing the Fusarium wilt of chickpea. Navas-
Cortes et al. (1998) concluded that changing date of sowing is the other important factor in curtailing losses due to Fusarium wilt as it can alter the varietal/ genotype resistance. Hence, it becomes imperative to study the influence of host resistance on Fusarium wilt dynamics in chickpea.

Multivariate analysis of disease progress curve helps in discerning the structure of epidemic by highlighting the phase during which maximum rate of multiplication of pathogen takes place. Several models viz. linear, Gompertz, exponential, ChapmanRichards, logistic and Weibull have been used to determine the temporal pattern of disease development in plants (Campbell and Madden, 1990). Navas-Cortes et al. (2001) found that relative frequency with which a model provided best fit to data, was influenced by the date of sowing, the chickpea cultivars, $F$. oxysporum f. sp. ciceris races and initial inoculum rates.

For sustainable chickpea production, it is advisable to identify strategies which can curtail farmers' need of fungicide application. A meager information is available on disease progression in chickpea varieties with varied disease resistance levels and date of sowing under field conditions. Thus, the present

Article info - DOI: https://doi.org/10.54386/jam.v24i1.1028

Received: 17 August 2021; Accepted: 24 December 2021; Published online: 11 February 2022

This work is licenced under a Creative Common Attribution 4.0 International licence @ Author(s), Publishing right @ Association of Agrometeorologists 
research was framed to study the effect of varieties, sowing time and weather parameters on disease severity index and progression; to estimate the proportion of Fusarium wilt epidemic determined by genetic resistance level of chickpea varieties and manipulation of environmental conditions by altering sowing time and to develop an appropriate model for temporal development of Fusarium wilt in three varieties having different resistance level.

\section{MATERIALS AND METHODS}

\section{Experimental set up}

To study the effect of weather parameters, varietal resistance level and sowing time on disease progression, field experiments were conducted in factorial randomized block design with three replications using a susceptible (JG 62), a moderately susceptible (C 235) and a resistant (HC 1) chickpea cultivar in Fusarium oxysporum $\mathrm{f}$. sp. ciceris infected sick plot at experimental area of CCS HAU, Hisar (Latitude: $29^{\circ} 10^{\prime} \mathrm{N}$, Longitude: $75^{\circ} 46^{\prime}$ E and Altitude: $215 \mathrm{~m}$ AMSL). The seeds of the above-mentioned cultivars were sown in plots of $3 \times 2 \mathrm{~m}^{2}$ with a row to row and plant to plant spacing of $30 \mathrm{~cm}$ and $10 \mathrm{~cm}$, respectively on four different dates/environments i.e. first fortnight of October (D1: $6^{\text {th }}$ October, 2018 and $7^{\text {th }}$ October, 2019), second fortnight of October (D2: $20^{\text {th }}$ October, 2018 and $22^{\text {nd }}$ October, 2019), first fortnight of November (D3: $6^{\text {th }}$ November, 2018 and $7^{\text {th }}$ November,2019) and second fortnight of November (D4: $20^{\text {th }}$ November, 2018 and 22 ${ }^{\text {nd }}$ November, 2019) during Rabi seasons of 2018-19 and 2019-20. The crop was raised following recommended package of practices for chickpea cultivation.

\section{Disease assessment}

The observations on disease severity were recorded at weekly interval on ten randomly selected plants per plot starting from disease initiation to crop maturity on a 0 to 4 rating scale on the basis of the percentage of foliage with yellowing or necrosis in acropetal progression $(0=0 \%, 1=1$ to $33 \%, 2=34$ to $66 \%, 3=67$ to $100 \%$, and $4=$ dead plant) as described by Landa et al. (2004). Disease severity index (DSI) was calculated using the formula given by Basavraj et al. (2020). The resistance index of each variety was determined by subtracting the highest disease severity index from 100 (Liu et al., 2021). The weather data of the rabi seasons of 2018-19 and 2019-20 were obtained from the nearby AgroMeteorological Observatory situated in the research farm of CCS Haryana Agricultural University, Hisar.

\section{Statistical analysis}

The disease development of Fusarium wilt was assessed by calculating area under the disease progress curve (AUDPC) by adopting standard procedure given by Van der Plank (1963). The effect of variety and date of sowing on disease severity index and AUDPC was determined by performing analysis of variance (ANOVA) followed by least significant difference (LSD) test using agricolae package of Rstudio. Coefficient of correlation for disease severity index was calculated with the weather variables namely, temperature maximum $\left(\mathrm{T}_{\max }\right)$, temperature minimum $\left(\mathrm{T}_{\text {min }}\right)$, relative humidity morning $\left(\mathrm{RH}_{\mathrm{M}}\right)$ and relative humidity evening $\left(\mathrm{RH}_{\mathrm{E}}\right)$ for different sowing environments. The correlation coefficient was figured out by performing correlation analysis using OPSTAT software. Principal component analysis (PCA) was performed to estimate the governing factors of Fusarium wilt epidemic. The PCA was applied on average data of 2018-19 and 2019-20 for number of days having temperature between $20-30^{\circ} \mathrm{C}(\mathrm{Td})$, number of days with relative humidity more than $60 \%(\mathrm{RHd})$, average DSI, resistance index, days taken for disease initiation, AUDPC, variety and sowing time to assess the inter-relationship among the factors of disease variability. The PCA results were further used for multivariate regression analysis with average DSI as dependent variable for the regression equation. The adjusted coefficient of determination $\left(\mathrm{R}^{2}\right)$ was used in the stepwise procedure to select the predictor variables using Sigma plot v14.5.

Temporal pattern of Fusarium wilt was studied by subjecting weekly DSI data to linear () and different non-linear regression analysis viz. Power: , Gompertz: , and Exponential:, where $\mathrm{Y}=$ estimated DSI, $\mathrm{t}=$ number of days after sowing. Model validation was done to determine the goodness of fit of model. The adequacy of fitted model was decided on the basis of adj $\mathrm{R}^{2}$, Akaike information criterion (AIC) and predicted residual error sum of square (PRESS). The model diagnostic analysis was done by Durbin Watson statistical analysis to show the absence of correlations among residuals.

\section{RESULTS AND DISCUSSION}

\section{Effect of date of sowing and variety on disease severity index and progression}

In susceptible chickpea variety JG 62 and moderately susceptible variety C 235, DSI followed the non-linear curve while in resistant variety $\mathrm{HC} 1$, curve followed the linear trend. In varieties JG 62 and $\mathrm{C} 235$, the disease initiation was early i.e. 94 and 98 days after sowing, respectively while in resistant variety HC 1 disease onset was observed after 120 days of sowing. In both the susceptible varieties, the curve became steeper after 120 days of sowing but in resistant variety curve followed the linear pattern even under congenial environmental conditions (Fig. 1). The disease progression can be manipulated by level of varietal resistance, pathogen virulence, environmental conditions and interaction between host genotype and environment (Campbell and Madden, 1990). The resistance factor of the varieties curtailed the DSI and AUDPC. The susceptible variety JG 62 had the higher DSI i.e. 49.68 and 41.87 per cent during 2018-19 and 2019-20 seasons while resistant variety HC 1 had the lower DSI of 5.93 and 5.51 per cent, respectively. The results were in corroboration with the findings of Landa et al. (2004) where overall Fusarium wilt development was slowed down in partially resistant cultivars CA255 and CA-252 compared to ICCV-4 and PV-61.

Sowing time of chickpea influenced the congenial days having temperature between $20-30^{\circ} \mathrm{C}$ and relative humidity $>60 \%$. In first fortnight of October sown varieties, the number of congenial days with respect to temperature were 56 and 49, while with relative humidity were 161 and 168 during rabi seasons of 2018-19 and 201920, respectively. However, in second fortnight of November sown varieties, the days with congenial temperature and relative humidity were 21 and 14 and 133 and 140, respectively. As a result, the DSI 
Table 1: Factors affecting disease severity index (DSI) and area under disease progress curve (AUDPC) during chick pea growing seasons

\begin{tabular}{|c|c|c|c|c|}
\hline \multirow{2}{*}{ Variable } & \multicolumn{2}{|c|}{ Rabi 2018-19 } & \multicolumn{2}{|c|}{ Rabi 2019-20 } \\
\hline & DSI (\%) & AUDPC & DSI (\%) & AUDPC \\
\hline JG 62 & $49.68 \mathrm{a}$ & $1788.28 \mathrm{a}$ & $41.87 \mathrm{a}$ & $1472.91 \mathrm{a}$ \\
\hline C 235 & $31.25 \mathrm{~b}$ & $1181.98 \mathrm{~b}$ & $29.79 \mathrm{~b}$ & $1109.06 \mathrm{~b}$ \\
\hline D1 & $34.86 \mathrm{a}$ & $1325.62 \mathrm{a}$ & $30.41 \mathrm{a}$ & $1117.56 \mathrm{a}$ \\
\hline $\mathrm{D} 2$ & $32.22 \mathrm{~b}$ & $1140.41 \mathrm{~b}$ & $27.63 \mathrm{~b}$ & $987.28 \mathrm{~b}$ \\
\hline JG 62:D1 & $58.33 \mathrm{a}$ & $2213.75 \mathrm{a}$ & $47.08 \mathrm{a}$ & $1713.54 \mathrm{a}$ \\
\hline JG 62:D2 & $55.42 \mathrm{~b}$ & $1926.46 \mathrm{~b}$ & $44.58 \mathrm{~b}$ & $1573.54 \mathrm{~b}$ \\
\hline JG 62:D3 & $45.42 \mathrm{c}$ & $1570.63 \mathrm{c}$ & $40.41 \mathrm{c}$ & $1381.04 \mathrm{c}$ \\
\hline JG 62:D4 & $39.58 \mathrm{~d}$ & $1442.29 \mathrm{~d}$ & $35.41 \mathrm{~d}$ & $1223.54 \mathrm{~d}$ \\
\hline C 235:D1 & $37.08 \mathrm{e}$ & $1418.96 \mathrm{~d}$ & $35.41 \mathrm{~d}$ & $1331.46 \mathrm{c}$ \\
\hline HC 1:D2 & $7.50 \mathrm{j}$ & $215.83 \mathrm{i}$ & $7.08 \mathrm{~h}$ & $193.96 \mathrm{~h}$ \\
\hline HC 1:D3 & $4.58 \mathrm{k}$ & $126.88 \mathrm{j}$ & $4.16 \mathrm{i}$ & $105.00 \mathrm{i}$ \\
\hline HC 1:D4 & 2.501 & $61.25 \mathrm{j}$ & $2.08 \mathrm{i}$ & $53.96 \mathrm{i}$ \\
\hline
\end{tabular}

2018-19
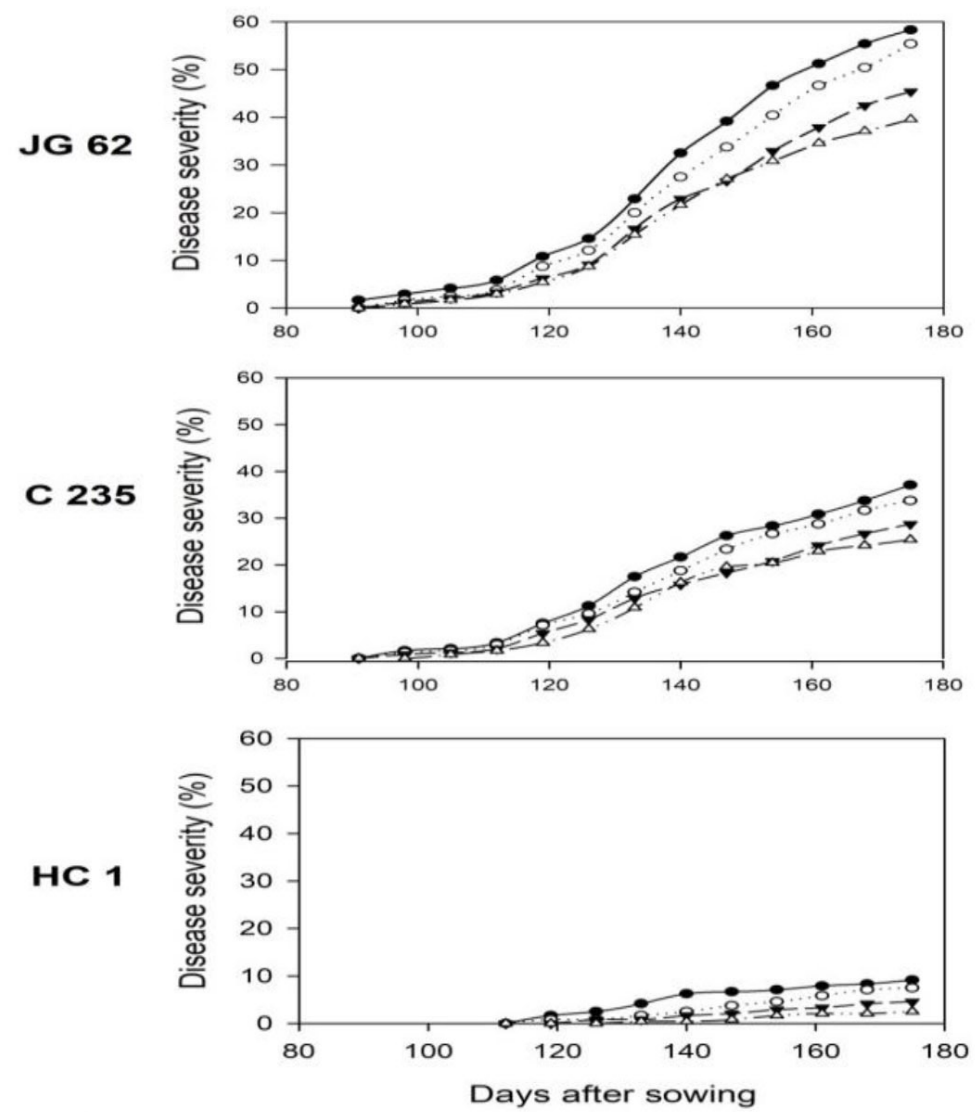

2019-20
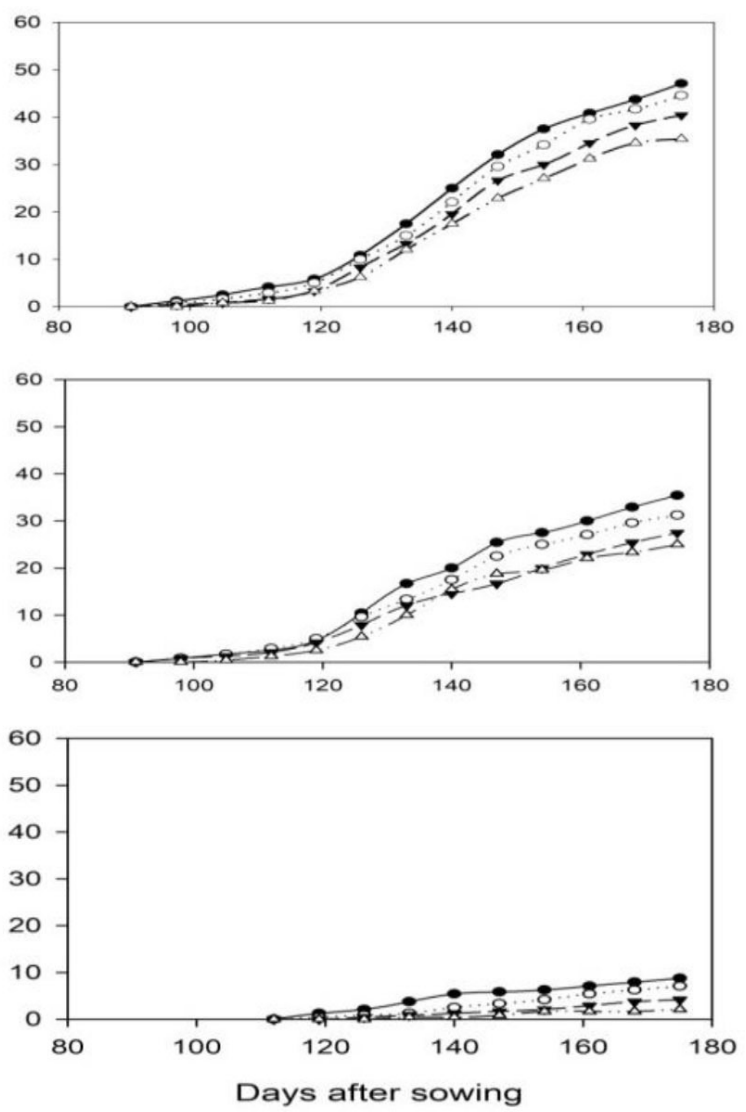

$\begin{array}{ll}\bullet \ldots \ldots \ldots & \text { D1 } \\ \text { D2 }\end{array}$ $\begin{array}{ll}--\div-- & \text { D3 } \\ -\cdots-\cdots & \text { D4 }\end{array}$

Fig. 1 : Disease progress curve for three varieties JG 62, C 235 and HC 1 sown at different dates/times 
Table 2: Correlation of weather variables and date of sowing on Fusarium wilt in chickpea

\begin{tabular}{|c|c|c|c|}
\hline Variety & Weather variables & Rabi 2018-19 & Rabi 2019-20 \\
\hline \multirow[t]{4}{*}{ JG 62} & $\mathrm{~T}_{\max }$ & $0.91^{* *}$ & $0.91^{* *}$ \\
\hline & $\mathrm{T}_{\min }$ & $0.90^{* *}$ & $0.92^{* *}$ \\
\hline & $\mathrm{RH}_{\mathrm{M}}$ & $-0.83^{* *}$ & $-0.59^{*}$ \\
\hline & $\mathrm{RH}_{\mathrm{E}}$ & $-0.89^{* *}$ & $-0.35^{\mathrm{NS}}$ \\
\hline \multirow[t]{4}{*}{ C 235} & $\mathrm{~T}_{\max }$ & $0.89^{* *}$ & $0.94^{* *}$ \\
\hline & $\mathrm{T}_{\min }$ & $0.90^{* *}$ & $0.93^{* *}$ \\
\hline & $\mathrm{RH}_{\mathrm{M}}$ & $-0.82^{* *}$ & $-0.62^{*}$ \\
\hline & $\mathrm{RH}_{\mathrm{E}}$ & $-0.87^{* *}$ & $-0.38^{\mathrm{NS}}$ \\
\hline \multirow[t]{4}{*}{$\mathrm{HC} 1$} & $\mathrm{~T}_{\max }$ & $0.89^{* *}$ & $0.94^{* *}$ \\
\hline & $\mathrm{T}_{\min }$ & $0.90^{* *}$ & $0.93^{* *}$ \\
\hline & $\mathrm{RH}_{\mathrm{M}}$ & $-0.82^{* *}$ & $-0.62^{*}$ \\
\hline & $\mathrm{RH}_{\mathrm{E}}$ & $-0.87^{* *}$ & $-0.38^{\mathrm{NS}}$ \\
\hline
\end{tabular}

was maximum in October (first fortnight) sown (34.86 and 30.41\%) and minimum in November (second fortnight) sown (22.50 and $20.83 \%$ ) varieties during rabi seasons of 2018-19 and 2019-20. Early sowing during first fortnight of October favored the wilt severity in all the three varieties while sowing during the month of November significantly reduced the DSI. The results were in consonance with the findings of Jamil and Ashraf (2021) that the optimum sowing time for plant growth and yield was $20^{\text {thn }}$ November. Mina and Dubey (2010) found that the disease incidence was lowest in $10^{\text {th }}$ and $20^{\text {th }}$ November sown chickpea cultivars Pusa 212 and BGD 1005 crop along with enhanced seed yield. In different combinations of variety and date of sowing, DSI ranged from 58.33 to 2.50 per cent during 2018-19 and 47.08 to 2.08 per cent during 2019-20, reflecting that resistance behaviour of variety could be predisposed with early sowing (Table 1). Reduction in disease progression in late sown chickpea crop was attributed to the resistance level of chickpea variety (Navas-Cortés et al., 2000). Similar trend was observed in AUDPC and maximum AUDPC was recorded in crop sown in early October (1325.62 and 1117.56) and minimum in late November (825.41 and 732.08) sown crop during both the rabi seasons (Table 1).

Correlation of weather variables and sowing time on Fusarium wilt in chickpea

Table 3: Multivariate regression analysis results for the Fusarium wilt disease of chickpea

\begin{tabular}{|c|c|c|c|c|c|c|}
\hline Variables & Parameter estimate & Standard error & $\mathrm{p}$ value & Adjusted $\mathrm{R}^{2}$ & DW test & Shapiro Wilk test \\
\hline Constant & 41.195 & 0.676 & & & & \\
\hline Resistance index & -0.414 & 0.007 & $<0.001$ & 0.997 & 1.54 & 0.730 \\
\hline
\end{tabular}

* Td- Number of days with mean temperature between $20-30^{\circ} \mathrm{C}$; RHd- Number of days with relative humidity $>60 \%$

Table 4: Statistical model for regression analysis of temporal disease progress

\begin{tabular}{|c|c|c|c|c|c|c|c|}
\hline Variety & Model & & timation & $\operatorname{adj} R^{2}$ & AIC & PRESS & DW test \\
\hline \multirow[t]{2}{*}{ JG 62} & Gompertz & A & 55.060 & 0.999 & -2.298 & 6.013 & 0.82 \\
\hline & & $\mathrm{B}$ & 22.300 & & & & \\
\hline \multirow{2}{*}{ C 235} & Gompertz & A & 34.280 & 0.999 & -11.895 & 3.591 & 1.39 \\
\hline & & $\mathrm{B}$ & 21.050 & & & & \\
\hline \multirow[t]{2}{*}{$\mathrm{HC} 1$} & Linear & A & -11.050 & 0.997 & -33.049 & 0.128 & 2.03 \\
\hline & & $\mathrm{B}$ & -0.090 & & & & \\
\hline
\end{tabular}

The correlation matrix of disease severity index with weather variables in chickpea varieties revealed that during rabi season of 2018-19, the maximum and minimum temperatures $\left(\mathrm{T}_{\max }\right.$ and $\mathrm{T}_{\min }$ ) were significantly positively correlated with DSI while relative humidity morning $\left(\mathrm{RH}_{\mathrm{M}}\right)$ and relative humidity evening $\left(\mathrm{RH}_{\mathrm{E}}\right)$ were negatively correlated. Similar pattern was observed during rabi season of 2019-20 with respect to all the above mentioned weather variables except for $\mathrm{RH}_{\mathrm{M}}$ in variety $\mathrm{HC} 1$ and $\mathrm{RH}_{\mathrm{E}}$ in all the varieties (Table 2). Landa et al. (2001) also reported that Fusarium wilt was favored within a temperature range of 20 $30^{\circ} \mathrm{C}$ with an optimum temperature range of 24.8 to $28.5^{\circ} \mathrm{C}$ while, Sudharani et al. (2019) observed that higher temperature levels of 25,30 and $35^{\circ} \mathrm{C}$ predisposed chickpea to wilt infection with
100 per cent disease incidence and maintained the virulence of $F$. oxysporum f. sp. ciceris.However, in this study, the highest chickpea wilt progression was recorded when $\mathrm{T}_{\max }$ ranges from 19.6 to $23.2^{\circ} \mathrm{C}$.

\section{Estimation of factors governing Fusarium wilt epidemics}

From the PCA, two principal components accounting for 97.80 per cent of the total variance characterized the disease progress curve in different chickpea varieties planted at different times. PC1 accounted for 64.05 per cent data variance and considered as major descriptor of the chickpea Fusarium wilt epidemics. It showed positive loading for AUDPC and average DSI and gave negative loading for the three descriptors i.e. variety, resistance index and 
disease initiation. PC2 accounted for 33.75 per cent variance in data showing positive loadings for number of days with mean temperature between $20-30^{\circ} \mathrm{C}$ and number of days with relative humidity $>60 \%$ and negative loading for the sowing dates/times. The PCA results for Fusarium wilt showed that the disease severity was dependent on resistance index, weather and sowing time (Table 3). Navas-Cortes et al. (1998) observed that the major governing factors contributing to the chickpea Fusarium wilt epidemics were time to inflection point, disease onset, standardized area under disease intensity index (DII) progress curves, the final DII and point of inflection of the DII progress curve over time.

Multivariate regression analysis, carried out to predict average Fusarium wilt severity index revealed that resistance index and $\mathrm{Td} \times \mathrm{RHd}$ were the major descriptors of DSI contributing to $99.7 \%$ of total variation (Table 4 ). These results corroborate with the findings of Landa et al. (2004) who also observed significant linear relationship between weather descriptors and disease progression over time.

\section{Temporal regression of Fusarium wilt in response to varietal resistance level}

The temporal pattern of Fusarium wilt of chickpea is greatly influenced by resistance level of the variety. In susceptible variety, temporal pattern was better explained by non-linear Gompertz model while in resistant variety, it was better explained by linear model. Disease epidemics incited by soil-borne pathogens have been explained by sigmoid curve (Bejarano-Alcázar et al., 1995). In variety JG 62, Gompertz model was adjudged as the best fitted model with highest adj $\mathrm{R}^{2}$ value of 0.999 and lowest AIC and PRESS value. Based on the selection criteria of highest adj $\mathrm{R}^{2}$ and lowest AIC \& PRESS values, the Gompertz model proved to be the best fitted model for the moderately susceptible variety C 235. Durbin Watson statistical value of Gompertz model (1.39) also fulfill the requisite assumptions and validation criterion of regression. In resistant variety $\mathrm{HC} 1$, linear model was found to be the most appropriate model in predicting the Fusarium wilt severity index. From the Durbin Watson statistical analysis, the linear equation (2.03) also fulfills the requisite validation criteria of regression (Table 5). The disease progression is generally best described by sigmoidal model but in few cases it can be better described by symmetric model (Navas-Cortes et al., 2000). The results of the present study corroborate with the findings of NavasCortes et al.(2007) who concluded Fusarium wilt progression over time was best described by quantitative non-linear model. Also, the best fitted statistical model for the estimation of Verticillium wilt disease progression in cotton was found to be sigmoidal (Gompertz) model (Liu et al., 2021).

\section{CONCLUSION}

This study expanded the knowledge on the role of weather variables, sowing time and varietal resistance in Fusarium wilt development in chickpea. The maximum and minimum temperatures were significantly positively correlated while morning time relative humidity was negatively correlated with disease severity. The resistance level of the cultivars was predisposed with early sowing whereas sowing in the month of November resulted in lesser disease severity. From the PCA, it was determined that disease progression over time can be interpreted by resistance index, sowing time and environmental conditions. The development of Fusarium wilt epidemic over time in chickpea can be determined by non-linear Gompertz model.

\section{ACKNOWLEDGEMENTS}

Authors are highly thankful to Chaudhary Charan Singh Haryana Agricultural University, Hisar, India for providing financial assistance in form of Merit Scholarship and required facilities to carry out the research work.

Conflict of Interest Statement: The author(s) declare(s) that there is no conflict of interest.

Disclaimer: The contents, opinions and views expressed in the research article published in Journal of Agrometeorology are the views of the authors and do not necessarily reflect the views of the organizations they belong to.

Publisher's Note: The periodical remains neutral with regard to jurisdictional claims in published maps and institutional affiliations.

\section{REFERENCES}

Anonymous. (2019). Area, production and productivity of gram in India. Agricultural Statistics at a Glance 2019, Government of India, Ministry of Agriculture, Directorate of Economics and Statistics, p. 63.

Basavaraj, K., Rathi, A. S., Gurav, N. P., Kumar, A., Rathod, S., and Niwas, R. (2020). Influence of weather variables on progression of white rust disease of Indian mustard. $J$. Agrometeorol., 22(3): 360-364.

Bejarano-Alcázar, J., Melero-Vara, J. M., Blanco-López, M. A. and Jiménez-Díaz, R. M. (1995). Influence of inoculum density of defoliating and non-defoliating pathotypes of Verticillium dahliae on epidemics of Verticillium wilt of cotton in southern Spain. Phytopathol.,85:1474- 1481.

Campbell, C. L. and Madden, L. V. (1990). Introduction to Plant Disease Epidemiology. John Wiley \& Sons, New York.

Jalali, B. L.and Chand, H. (1992). Chickpea wilt. In: Plant Diseases of International Importance. Vol. 1. Diseases of Cereals and Pulses. Eds. U. S. Singh, A. N. Mukhopadhayay, J. Kumar, and H. S. Chaube, Prentice Hall, Englewood Cliffs, NJ, pp. 429-444.

Jamil, A. and Ashraf, S. (2021). Impacts of agronomic practices in the management of Fusarium wilt of chickpea. Australasian Plant Pathol., 10: 1-10.

Jiménez-Díaz, R.M., Castillo, P., Jiménez-Gasco, M.M., Landa, B.B. and Navas Cortés, J.A. (2015). Fusarium wilt of chickpeas: Biology, ecology and management. Crop Prot.,73: 16-27.

Landa, B. B., Navas-Cortés, J. A. andJiménez-Díaz, R. M.(2004). 
Integrated management of Fusarium wilt of chickpea with sowing date, host resistance, and biological control. Phytopathol., 94(9): 946-960.

Landa, B.B., Navas-Cortés, J.A., Hervás, A. and Jiménez-Díaz, R.M.(2001). Influence of temperature and inoculum density of Fusarium oxysporum f. sp. ciceris on suppression of Fusarium wilt of chickpea by rhizosphere bacteria. Phytopathol., 91(8): 807-816.

Liu, X., Woodward, J. E., Kelly, B., Lewis, K. L., Byrd, S. A. and Chen, Y. (2021). Effects of production practices on temporal disease progress of Verticillium wilt of cotton (Gossypium hirsutum L.) in the Texas High Plains, USA. Crop Prot., 140: 105429.

Mina, U. and Dubey, S.C. (2010). Effect of environmental variables on development of Fusarium wilt in chickpea (Cicer arietinum) cultivars. Indian J. Agric. Sci., 80(3):231-234.

Navas-Cortés, J. A., Hau, B. and Jiménez-Díaz, R. M. (1998). Effect of sowing date, host cultivar, and race of Fusarium oxysporum f. sp. ciceris on development of Fusarium wilt of chickpea. Phytopathol., 88: 1338- 1346.
Navas-Cortés, J. A., Hau, B. and Jiménez-Díaz, R. M. (2000). Yield loss in chickpeas in relation to development of Fusarium wilt epidemics. Phytopathol., 90: 1269-1278.

Navas-Cortés, J. A., Landa, B. B., Méndez-Rodríguez, M. A., andJiménez-Díaz, R. M. (2007). Quantitative modeling of the effects of temperature and inoculum density of Fusarium oxysporum f. sp. ciceris races 0 and 5 on development of Fusarium wilt in chickpea cultivars. Phytopathol., 97(5): 564-573.

Sudharani, G. B. N., Naik, M. K., Shivanna, B. K., Satish, K. M. and Sharma, M. (2019). Effect of temperature on the severity of Fusarium wilt of chickpea caused by Fusarium oxysporum f. sp. ciceris. Int. J. Chem Stud., 7(5):27-30.

Tyagi, P. K. (2014). Thermal requirements, heat use efficiency and plant responses of chickpea (Cicer arietinum L.) cultivars under different environment. J. Agrometeorol., 16(2): 195-198.

Van der Plank, J. E. (1963). Plant Diseases, Epidemics and Control. Academic Press, New York, pp. 249-259. 